\title{
The association of plant-based dietary patterns with visceral adiposity, lipid accumulation product, and triglyceride-glucose index in Iranian adults
}

\author{
Mahshid shahavandi ${ }^{1}$, Farhang Djafari ${ }^{1}$, hossein shahinfar ${ }^{1}$, Samira Davarzani ${ }^{1}$, Nadia \\ Babaei $^{1}$, Mojdeh Ebaditabar ${ }^{1}$, kurosh djafarian ${ }^{1}$, Cain C.C. Clark ${ }^{2}$, and Sakineh \\ Shab-Bidar ${ }^{1}$ \\ ${ }^{1}$ Tehran University of Medical Sciences \\ ${ }^{2}$ Coventry University
}

June 22, 2020

\begin{abstract}
Abstract Background: We sought to investigate whether adherence to a more plant-based, and less animal-based, diet is associated with visceral adiposity, lipid accumulation product (LAP), and triglyceride-glucose index (TyG) in Iranian adults. Methods: This cross-sectional study was conducted on 270 adults aged between 18-75 years old. We created three plant-based diets. including an overall plant-based diet index (PDI), hPDI, and uPDI based on tertiles regarding the intake of animal- or plant-based food items obtained from a semi-quantitative food-frequency questionnaire. Results: Higher hPDI was significantly associated with lower body mass index $(\mathrm{BMI})(\mathrm{P}$-value $=0.01)$, lower waist circumference $(\mathrm{P}$-value $<0.001)$, and lower waist-hip ratio $(\mathrm{P}$-value $<0.001)$. A significant increase was found for high-density lipoproteins $(\mathrm{HDL})(\mathrm{P}$-trend $<0.001)$ with a significant decrease for LAP $(\mathrm{P}$-value $=0.03)$ in those with higher adherence to hPDI. Moreover, greater adherence to PDI was associated with a significant increase in diastolic blood pressure $(\mathrm{DBP})(\mathrm{p}$-value $=0.01)$ and fat free mass $(\mathrm{FFM})(\mathrm{p}$-value $=0.01)$. There were no significant associations between PDIs and TyG and VFA. Conclusion: We found that a higher hPDI score was significantly associated with better anthropometric measurements. A significant increase was found for HDL and a significant decrease was found for LAP on hPDI. However, a higher PDI score was significantly associated with higher DBP and higher FFM.
\end{abstract}

\section{Introduction}

Obesity, a progressive chronic disease, is a significant general medical issue, both in developed and developing countries, over the most recent 3 decades (1). Further, body fat distribution plays a significant role in metabolic syndrome incident involving obesity, insulin resistance, hyperinsulinemia, dyslipidemia, glucose intolerance, and hypertension. In general, visceral adiposity appears to play a central role in chronic disease as opposed to regional or generalized obesity (2). Several empirical studies have reported that diets focused on plant-based nutrients can elicit reductions in body weight and result in an improvement of chronic diseases, including cardiovascular diseases. Some biological pathways may also be considered as possible reasons behind this association, including changes in satiety, inflammation, and the composition of the gut microbiome (3). Plant-based diets have been related to a decreased risk of different disease sicknesses, along with (CHD), the leading worldwide contributor to loss of life (4). Most previous research investigating plant-based diets, compared those people who are vegetarian or vegan versus non vegetarians; whilst a limited number of research further labeled plant-based diets as semi-vegetarian, lactovegetarian, and vegan diets, Nonetheless, the currently available evidence has failed to cope with variation in plant-based diets $(5,6)$, largely because most general groups of people do not follow a strict vegan or vegetarian diets. The extent to which adherence to an overall more plant-based and less animal-based diet influences adiposity 
(7), and is associated with chronic disease, is of great interest. In general, three plant-based indices have evolved typically consists of a plant-based diet index (PDI), a healthy plant-based diet index (hPDI), and an unhealthy plant-based diet index (uPDI). The hPDI offers a high-quality plant-based diet rich in whole grains, fruits, vegetables, and nuts and poor in fruit juices, refined grains, and sweets, while uPDI is the opposite (7). Presently, however, the association between plant-based diets and adiposity-related biomarkers remains unknown $(4,8)$. Therefore, we sought to investigate whether adherence to a more plant-based and less animal-based diet is associated with visceral adiposity, lipid accumulation product, and triglycerideglucose index in Iranian adults.

\section{Subjects and Methods}

\section{Study design}

A total of 270 adults (118 males and 152 females) aged between 18-75 years old were enrolled in this cross-sectional study. After a full description of the study objectives, all participants provided written informed consent. Participants were recruited based on inclusion criteria, including an age range of 18-75 years and willingness to participate in our study, and exclusion criteria, including diagnosed chronic diseases such as kidney, liver and pulmonary disease, diabetics, hormonal and cardiovascular diseases, pregnant and lactating women, receiving any special medication or supplements (slimming medicine, hormone, sedative, supplements containing thermogenic substances such as caffeine and green tea, linoleic acid conjugate etc.), and people affected with active infectious or inflammatory diseases. According to inclusion and exclusion criteria, subjects were chosen and interviewed to collect data on demographics, smoking status, physical activity, diet, and supplement use; following which, an anthropometric assessment was conducted.

\section{Diet assessment}

Regular dietary intake was evaluated using a valid and reliable 168-item semiquantitative food frequency questionnaire (sq-FFQ). Respondents were asked to select, on a daily, weekly, or monthly basis, the usual frequency of food intakes with a standard serving size during the past year. Previously, the validity and reliability of this FFQ were confirmed (9). Based on household measures, portion sizes of food eaten were calculated in grams per day (10). To evaluate dietary nutrient intakes, dietary intakes were analyzed using $\mathrm{Nu}-$ tritionist IV software.

\section{Covariates}

Physical activity, age, sex, education, smoking, marital status were included as covariates in the present study. Participants completed a questionnaire designed to assess the participants' demographic (age, education, sex and marital status), lifestyle, such as smoking and physical activity. Educational status was categorized into illiterate, under diploma, diploma, and educated. Marital status categorized into married or single. Smoking was classified as non-smoker, former, or current smoker. Physical activity was grouped into low, moderate and high

\section{Calculation of plant-based-diet}

We developed a general plant-based diet index (PDI), a healthful plant-based diet index (hPDI), and an unhealthful plant-based diet index (uPDI) (Table $\mathbf{1}$ ) following a procedure similar to that of MartínezGonzález et al (11). For PDI, respondents obtained a rating of 5 for each set of plant foods for which they were above the largest quintile of intake, a result of 4 for each set of plant food for which they were above the second largest quintile but below the lowest quintile and so on, with a score of 1 for consumption below the lowest quintile (positive scores). On the other hand, for each animal food group, participants received a score of 1 in instances they were above the highest quintile of consumption, a score of 2 for each animal food group for which they were between the highest and second highest quintile, and so on, with a score of 5 for consumption below the lowest quintile (reverse scores).

For hPDI, healthy plant food groups were provided positive ratings, and less heal- 
thy plant food groups and animal food groups were reversed results. Finally, for uPDI, positive ratings were given to less safe groups of plant foods and inverse scores were given to healthy groups of plant foods and animal groups(8). Finally, in order to generate their general rating on the plant-based dietary index, these quintile-scores categories were implemented for each person.

\section{Anthropometric measures and body composition}

Height was measured, with participants unshod, by a stadiometer (Seca, Germany), and other parameters such as weight, body mass index (BMI), waist-hip ratio and waist circumference and body composition including, fat mass, fat-free mass, body fat percentage, total body fat, visceral fat mass, abdominal fat mass were measured using the InBody analyzer (InBody 720, Biospace, Tokyo, Japan).

\section{Physical activity}

Physical activity was assessed using a validated short form of the International Physical Activity Questionnaire (IPAQ) (12). Subjects were grouped into three categories, including very low $(<600$ METminute/week), low (600-3000 MET-minute/week), moderate and high (>3000 MET-minute/week), calculated based on Metabolic Equivalents (METs) (13).

\section{Blood pressure}

Blood pressure was measured twice, with participants in a seated position, after a 10-15-minute rest, using a digital sphygmomanometer (Beurer, BC 08, Germany), and the mean of the two measurements was considered as the participant's systolic and diastolic blood pressure.

\section{Laboratory investigations}

A $20 \mathrm{ml}$ blood sample was obtained between the hours of 07:30-09:00 (am) from all participants, following an overnight fast. Then, the blood samples were collected in acid-washed test tubes without anticoagulant. After storing at room temperature for 30 minutes and clot formation, blood samples were centrifuged at $1500 \mathrm{~g}$ for 20 minutes. Serums were stored in $-80^{\circ} \mathrm{C}$ until future testing. Glucose was evaluated using a commercial kit (Pars Azmun, Tehran, Iran), by the enzymatic (glucose oxidase) colorimetric method. Serum TC and HDL-C were measured using a cholesterol oxidase phenol aminoantipyrine method, and TG was measured using a glycerol-3 phosphate oxidase phenol aminoantipyrine enzymatic method. Serum LDL-C was calculated using the Friedewald formula.

\section{Definitions}

The triglyceride (TG)-glucose $(\mathrm{TyG})$ index was calculated as the ln (Fasting TG[mg/dL] $\times$ Glucose $[\mathrm{mg} / \mathrm{dL}] / 2)(14)$. LAP was calculated as $(\mathrm{WC}-65) \times \mathrm{TG}$ in men, and $(\mathrm{WC}-58) \times \mathrm{TG}$ in women(15). We categorized general obesity by using body mass index (BMI) where values $>30 \mathrm{~kg} / \mathrm{m}^{2}$ defined as obesity (16). According to the NCEP-ATP III classification, central obesity was defined as waist circumference $>102 \mathrm{~cm}$ for men and $\mathrm{WC}>88 \mathrm{~cm}$ for females, fasting plasma glucose [?]5/6mmol/l, or a known diagnosis diabetes, fasting serum triglyceride [?]1.7mmol/l, fasting high-density lipoprotein (HDL) cholesterol $<40 \mathrm{mg} / \mathrm{dl}$ for men and HDL $<50 \mathrm{mg} / \mathrm{dl}$ for females, or blood pressure [?] $130 / 85 \mathrm{mmHg}(17)$. Moreover, we categorized participants into two groups based on median of values for TyG index, LAP, visceral adiposity. LAP and TyG were converted to binary variables based on their median values (Median $\mathrm{TyG}=8.49$; median $\mathrm{LAP}=32.28$ ).

\section{Statistical analysis}

Differences, by type of plant based-dietary index (PDI, hPDI, uPDI), were evaluated using Analysis of Variance (ANOVA) and by $\chi^{2}$ tests for categorical data. Analysis of Covariance (ANCOVA) was used in comparing traditional CVD risk factors (HDL, TG, TC, LDL, glucose, and blood pressure) and body composition by types of plant-based dietary indices. Logistic regression analysis was used to compute multivariable-adjusted odds ratios (ORs) and 95\% CIs for the association of plant-based dietary indexes with CVD risk factors. Adjustments were made for age, sex, diabetes, cardiovascular disease (CVD), menopause status, education status smoking, physical activity, and dietary energy intake in the ANCOVA and logistic 
regression analysis. All statistical analyses were performed using The Statistical Package for the Social Sciences (SPSS version 25; SPSS Inc). We considered $\mathrm{p}<0.05$ to represent statistical significance.

\section{Results}

Characteristics of participants according to tertile of PDI, hPDI, and uPDI are presented in Table 2. A total of 270 participants (118 men and 152 women) were included in this study, with a mean age of 36.52 years old and mean BMI of 25.44. Participants with higher scores on PDI or hPDI were more active and less likely to smoke than lower scoring counterparts. Moreover, participants in the highest tertile of hPDI were well educated. Adherence to hPDI was significantly associated with lower BMI $(p=0.01)$, lower waist circumference $(\mathrm{p}<0.001)$, and lower waist-hip ratio $(\mathrm{p}<0.001)$; whilst a decrease was found for FFM across tertiles of hPDI $(\mathrm{p}=0.06)$. Participants in the lowest tertile of PDI had a lower weight $(\mathrm{p}=0.01)$ and FFM $(\mathrm{p}=0.02)$. (Table 2). Table 3 details mean and standard deviation of food groups across tertiles of PDI, hPDI, and uPDI scores. Adherence to PDI was significantly associated with greater intake of fruits $(\mathrm{p}<0.001)$, vegetables $(\mathrm{p}=0.001)$, nuts $(\mathrm{p}<0.001)$, legumes $(\mathrm{p}<0.001)$, tea and coffee $(\mathrm{p}=0.02)$, refined grains $(\mathrm{p}<0.001)$, sugar sweetened $(\mathrm{p}<0.01)$, and sweets and dessert $(\mathrm{p}<0.001)$. Adherence to hPDI was also significantly associated with greater intake of fruits $(\mathrm{p}<0.01)$, nuts $(\mathrm{p}=0.02)$, vegetables oils $(\mathrm{p}<0.001)$ and lower intake of fruit juices $(\mathrm{p}<0.01)$, refined grains $(\mathrm{p}<0.001)$, potatoes $(\mathrm{p}<0.001)$, sugar sweetened $(\mathrm{p}<0.001)$, sweets and dessert $(\mathrm{p}<0.001)$, other $(\mathrm{p}<0.001)$, dairy and egg $(\mathrm{p}<0.01)$. Participants in the highest tertile of uPDI consumed higher levels of refined grains $(\mathrm{p}=0.04)$, sugar sweetened $(\mathrm{p}<0.001)$, sweets and dessert $(\mathrm{p}=0.01)$ and had lower intake of fruits, vegetables, nuts, legumes, vegetables oils, animal fat, dairy, meat $(\mathrm{p}<0.001)$, whole grains $(\mathrm{p}=0.02)$, tea and coffee $(\mathrm{p}<0.01)$, and egg and fish or seafood $(\mathrm{p}=0.01)$ (Table 3). Dietary intake of study participants across tertiles of PDI, hPDI, and uPDI scores are indicated in Table 4 . Intake of riboflavin, niacin, pyridoxine, folate, vitamin B12, vitamin E, vitamin $\mathrm{C}$, vitamin $\mathrm{K}$, potassium, calcium, magnesium, iron, zinc ( $\mathrm{p}$ value $<0.001$ for all comparisons) and thiamin was lower ( $\mathrm{p}$-value $=0.02$ ) in the highest tertile of uPDI, and greater in the highest tertile PDI groups. Those in the highest tertile of hPDI had a lower intake of calcium, selenium, vitamin E, and thiamin, and higher vitamin A. Mean and standard deviation of body composition and traditional CVD risk factors across tertiles of PDI, hPDI, and uPDI scores are indicated in Table 5 . A significant increase was found for DBP ( $\mathrm{p}$-value $=0.01$ ), and FFM $(\mathrm{p}$-value $=0.01)$ across tertiles of PDI. Adherence to hPDI showed a significant increase for HDL $(P$-trend $<$ $0.01)$ and a significant decrease for LAP $(P$-value $=0.03)$. In contrast, we did not observe any significant associations between adherence to uPDI and central obesity biomarkers (Table 5).Multivariable-adjusted odds ratio (OR) and $95 \%$ confidence intervals (CIs) for CVD risk factors across tertiles of PDI, hPDI, and uPDI are indicated in Table 6 . Participants in the highest tertile of PDI had a lower chance of general obesity $(\mathrm{p}$-value $=0.1)$, hypertension $(\mathrm{p}$-value $=0.9)$, hyperglycemia $(\mathrm{p}$-value $=0.1)$, TyG $(\mathrm{p}$-value $=0.9)$, and LAP (p-value $=0.9)$, but results were not statistically significant. There was also no statistically significant association across tertiles of hPDI with general obesity ( $\mathrm{p}$-value $=0.2)$, central obesity ( $\mathrm{p}$-value $=0.6), \operatorname{TyG}(\mathrm{p}-$ value $=0.7)$, and visceral adiposity $(\mathrm{p}$-value $=0.3)$. Moreover, there was no association for chance of visceral adiposity $(\mathrm{p}$-value $=0.05)$, general obesity $(\mathrm{p}$-value $=0.3)$, central obesity $(\mathrm{p}$-value $=0.5)$, hypertension $(\mathrm{p}-$ value $=0.2)$, hypertriglyceridemia $(\mathrm{p}$-value $=0.5)$, higher $\mathrm{LAP}(\mathrm{p}$-value $=0.5)$, and higher TyG $(\mathrm{p}$-value $=0.5)$ across tertiles of uPDI. Our results showed that there was no significant difference in the odds of CVD risk factors, or higher levels of LAP and TyG index, across tertiles of PDI, hPDI and uPDI, even after controlling for potential confounders (Table 6).

\section{Discussion}

This cross-sectional study revealed that adherence to the hPDI was significantly associated with lower BMI, body weight, FFM, WC, and waist-hip ratio. Furthermore, a significant decrease in LAP was associated with adherence to hPDI. However, we did not observe any significant association between adherence to uPDI and central obesity. We found no statistically significant increased odds for visceral adiposity, general obesity, central obesity, hypertension, hypertriglyceridemia, higher LAP, and higher TyG across the tertiles of PDI, hPDI, and uPDI.

According to our results, a greater intake of fruits, nuts, vegetable oils, and a lower intake of fruit juices, 
refined grains, potatoes, sugar-sweetened, sweets and dessert, and dairy and egg was related to greater adherence to hPDI. In Panagiotakos et al (18), subjects with high adherence to hPDI were significantly protected against CVD; whilst a $25 \%$ reduction in CVD events for men and an approximately $10 \%$ reduction for women were also reported. In the European Prospective Investigation into Cancer and Nutrition study (19), a $32 \%$ lower risk of progressing CHD was observed for vegetarians compared with non-vegetarians. A low-fat, vegetarian diet is the only dietary pattern to have shown protective influences against atherosclerotic plaque formation in clinical trials $(20,21)$, particularly when combined with exercise and stress management. Vegetarian diets are often more healthful because they contain lower amounts of total fat, saturated fat, cholesterol, and total energy, while rich in polyunsaturated fatty acids, fiber, vitamins $\mathrm{C}$ and $\mathrm{E}$, folate, iron, magnesium, and copper (22). Fiber contributes to 'bulk out' the diet without any calories, consequently, this triggers satiety and weight loss. Moreover, soluble fiber binds with bile acids in the small intestines, increasing fecal bile salt excretion and thus reducing cholesterol (23), and moderating post-prandial insulinemic and glycemic responses (24). Therefore, a high fiber consumption, accomplished with greater adherence to a plant-based diet, has been associated with decreased body weight, lower blood pressure and blood lipids, reduced plaque development and cardiovascular risk, and lower risk of type 2 diabetes (25-27). Another factor is vegetable proteins which can act to decrease the levels of blood lipids, and reduce the risk of obesity and cardiovascular disease and is attributed to the maximization of hepatic fatty acid oxidation (28-31). High intake of antioxidants and micronutrients from whole plant foods represents another potential cardiometabolic beneficial mechanism (32). Indeed, the antioxidant capacity of polyphenol compounds, due to the scavenging of free radicals and protecting against oxidative stress is reported in in-vitro studies (33). This antioxidant capacity, potentially concomitant with their ability to modify nitric oxide (NO) production, potentiate the polyphenol compounds to maintain vascular homeostasis (34). Our findings showed that subjects in the highest tertile of uPDI consumed higher levels of refined grains, sugar-sweetened, sweets, and dessert, and had a lower intake of fruits, vegetable, nuts, legumes, vegetable oils, animal fat, dairy, meat, whole grains, tea and coffee, egg and fish or seafood. The results of Kim et al (35), who highlighted that higher consumption of animal foods and a higher risk of cardiovascular disease, cardiovascular disease mortality, and all-cause mortality are associated, are concordant with numerous observational studies that reported higher intakes of animal foods, particularly red and processed meat, are linked to an increased risk of these outcomes (36-39). Lower intake of animal protein and saturated fatty acids have been suggested to be beneficial for the prevention of obesity $(40,41)$. Moreover, animal protein is also rich in heme iron and other nutrients from red meat processing, such as sodium and nitrites, and have been suggested to increase the risk of cardio-metabolic diseases $(42,43)$. To the authors knowledge, the present study represents the first investigation into the association between the plant-based diet index with visceral adiposity, lipid accumulation product, and triglyceride-glucose index, which should be considered a major strength. In this paper, the food frequency questionnaire method was used to examine the dietary intake of patients, which is a validated, reliable, and robust tool that can reflect long-term dietary intake in adults. Furthermore, the recruitment of trained dieticians for the interviews to collect the food frequency data would be expected to decrease any possible misclassification error compared with self-administration. Moreover, we considered that the potential beneficial impacts of a more plant-based diet were independent of less healthy plant foods, for instance, sweets, sugary beverages, and refined grains, thereby the quality of plant-based foods ingested is important. In addition, we endeavored to adjust for all possible potential confounders. However, some limitations are unavoidable and must be considered. Due of the cross-sectional design, the likelihood of residual confounding cannot be ignored; moreover, the cross-sectional design prevents any causal inference being made.

\section{Conclusion}

In conclusion, the present study demonstrates that adherence to hPDI is associated with a significant decrease in LAP, lower BMI, body weight, FFM, WC, and waist-hip ratio. However, there was no significant relationship between the plant-based diet index (PDI) and the risk of obesity, hypertension, hypertriglyceridemia, higher LAP, and higher TyG among subjects. Our study highlights that more investigations into the relationship between PDI and MetS in large cohort studies and well-designed clinical trials are necessitated. 
Moreover, the importance of plant-based diet quality is critical and needs to be further explored.

\section{AcknowledgmentsNone.}

\section{Funding}

This research received no specific grant from any funding agency in the public, commercial, or not-for-profit sectors.

\section{References}

1. Azadbakht L, Haghighatdoost F, Esmaillzadeh A. White rice consumption, body mass index, and waist circumference among iranian female adolescents. Journal of the American College of Nutrition. 2016;35(6):4919.

2. Hayashi T, Boyko EJ, Leonetti DL, McNeely MJ. Visceral adiposity is an independent predictor of incident hypertension in Japanese Americans. Annals of internal medicine. 2004;140(12):992.

3. Chen Z, Schoufour JD, Rivadeneira F, Lamballais S, Ikram MA, Franco OH, et al. Plant-based Diet and Adiposity Over Time in a Middle-aged and Elderly Population: The Rotterdam Study. Epidemiology. 2019;30(2):303-10.

4. Satija A, Bhupathiraju SN, Spiegelman D, Chiuve SE, Manson JE, Willett W, et al. Healthful and unhealthful plant-based diets and the risk of coronary heart disease in US adults. Journal of the American College of Cardiology. 2017;70(4):411-22.

5. Rosell M, Appleby P, Spencer E, Key T. Weight gain over 5 years in 21966 meat-eating, fish-eating, vegetarian, and vegan men and women in EPIC-Oxford. International journal of obesity. 2006;30(9):1389.

6. Tonstad S, Butler T, Yan R, Fraser GE. Type of vegetarian diet, body weight, and prevalence of type 2 diabetes. Diabetes care. 2009;32(5):791-6.

7. Baden MY, Satija A, Hu FB, Huang T. Change in plant-based diet quality is associated with changes in plasma adiposity-associated biomarker concentrations in women. The Journal of Nutrition. 2019.

8. Satija A, Bhupathiraju SN, Rimm EB, Spiegelman D, Chiuve SE, Borgi L, et al. Plant-based dietary patterns and incidence of type 2 diabetes in US men and women: results from three prospective cohort studies. PLoS medicine. 2016;13(6):e1002039.

9. Mirmiran P, Esfahani FH, Mehrabi Y, Hedayati M, Azizi F. Reliability and relative validity of an FFQ for nutrients in the Tehran lipid and glucose study. Public health nutrition. 2010;13(5):654-62.

10. Morgan KJ, Zabik ME, Stampley GL. The role of breakfast in diet adequacy of the US adult population. Journal of the American College of Nutrition. 1986;5(6):551-63.

11. Martínez-González MA, Sanchez-Tainta A, Corella D, Salas-Salvado J, Ros E, Aros F, et al. A provegetarian food pattern and reduction in total mortality in the Prevención con Dieta Mediterránea (PREDIMED) study. The American journal of clinical nutrition. 2014;100(suppl_1):320S-8S.

12. Moghaddam MB, Aghdam FB, Jafarabadi MA, Allahverdipour H, Nikookheslat SD, Safarpour S. The Iranian Version of International Physical Activity Questionnaire (IPAQ) in Iran: content and construct validity, factor structure, internal consistency and stability. World applied sciences journal. 2012;18(8):107380.

13. Wareham NJ, Jakes RW, Rennie KL, Schuit J, Mitchell J, Hennings S, et al. Validity and repeatability of a simple index derived from the short physical activity questionnaire used in the European Prospective Investigation into Cancer and Nutrition (EPIC) study. Public Health Nutr. 2003;6(4):407-13.

14. Simental-Mendía LE, Rodríguez-Morán M, Guerrero-Romero F. The product of fasting glucose and triglycerides as surrogate for identifying insulin resistance in apparently healthy subjects. Metabolic syndrome 
and related disorders. 2008;6(4):299-304.

15. Kahn HS. The lipid accumulation product is better than BMI for identifying diabetes: a population-based comparison. Diabetes care. 2006;29(1):151-3.

16. Gallagher D, Heymsfield SB, Heo M, Jebb SA, Murgatroyd PR, Sakamoto Y. Healthy percentage body fat ranges: an approach for developing guidelines based on body mass index. The American journal of clinical nutrition. 2000;72(3):694-701.

17. Expert Panel on Detection E. Executive summary of the third report of the National Cholesterol Education Program (NCEP) expert panel on detection, evaluation, and treatment of high blood cholesterol in adults (Adult Treatment Panel III). Jama. 2001;285(19):2486.

18. Panagiotakos D, Kouvari M, Chrysohoou C, Georgousopoulou E, Tousoulis D, Pitsavos CJJotACoC. THE ASSOCIATION BETWEEN HEALTHFUL AND UNHEALTHFUL PLANT BASED DIETARY PATTERNS AND 10-YEAR CARDIOVASCULAR DISEASE INCIDENCE IN APPARENTLY HEALTHY MEN AND WOMEN: HIGHLIGHTS FROM THE ATTICA PROSPECTIVE (2002-2012) STUDY.75(11 Supplement 2):9.

19. Crowe FL, Appleby PN, Travis RC, Key TJJTAjocn. Risk of hospitalization or death from ischemic heart disease among British vegetarians and nonvegetarians: results from the EPIC-Oxford cohort study. 2013;97(3):597-603.

20. Ornish D, Brown SE, Billings J, Scherwitz L, Armstrong WT, Ports TA, et al. Can lifestyle changes reverse coronary heart disease?: The Lifestyle Heart Trial. 1990;336(8708):129-33.

21. Ornish D, Scherwitz LW, Billings JH, Gould KL, Merritt TA, Sparler S, et al. Intensive lifestyle changes for reversal of coronary heart disease. 1998;280(23):2001-7.

22. Sobiecki JG, Appleby PN, Bradbury KE, Key TJJNR. High compliance with dietary recommendations in a cohort of meat eaters, fish eaters, vegetarians, and vegans: results from the European Prospective Investigation into Cancer and Nutrition-Oxford study. 2016;36(5):464-77.

23. Gunness P, Gidley MJJF, function. Mechanisms underlying the cholesterol-lowering properties of soluble dietary fibre polysaccharides. 2010;1(2):149-55.

24. Howarth NC, Saltzman E, Roberts SBJNr. Dietary fiber and weight regulation. 2001;59(5):129-39.

25. Melina V, Craig W, Levin SJJotAoN, Dietetics. Position of the academy of nutrition and dietetics: vegetarian diets. 2016;116(12):1970-80.

26. Pettersen BJ, Anousheh R, Fan J, Jaceldo-Siegl K, Fraser GEJPhn. Vegetarian diets and blood pressure among white subjects: results from the Adventist Health Study-2 (AHS-2). 2012;15(10):1909-16.

27. Smit E, NIETO FJ, Crespo CJ, Mitchell PJJotADA. Estimates of animal and plant protein intake in US adults: results from the Third National Health and Nutrition Examination Survey, 1988-1991. 1999;99(7):81320.

28. Jenkins DJ, Wolever TM, Spiller G, Buckley G, Lam Y, Jenkins AL, et al. Hypocholesterolemic effect of vegetable protein in a hypocaloric diet. 1989;78(2-3):99-107.

29. Anderson JW, Smith BM, Washnock CSJTAJoCN. Cardiovascular and renal benefits of dry bean and soybean intake. 1999;70(3):464s-74s.

30. McCarty MJMh. Vegan proteins may reduce risk of cancer, obesity, and cardiovascular disease by promoting increased glucagon activity. 1999;53(6):459-85.

31. McCarty MFJMh. Promotion of hepatic lipid oxidation and gluconeogenesis as a strategy for appetite control. 1994;42(4):215-25. 
32. Benzie IF, Choi S-W. Antioxidants in food: content, measurement, significance, action, cautions, caveats, and research needs. Advances in food and nutrition research. 71: Elsevier; 2014. p. 1-53.

33. Tangney CC, Rasmussen HEJCar. Polyphenols, inflammation, and cardiovascular disease. 2013;15(5):324.

34. Quiñones M, Miguel M, Aleixandre AJPr. Beneficial effects of polyphenols on cardiovascular disease. 2013;68(1):125-31.

35. Kim H, Caulfield LE, Garcia-Larsen V, Steffen LM, Coresh J, Rebholz CMJJotAHA. Plant-Based Diets Are Associated With a Lower Risk of Incident Cardiovascular Disease, Cardiovascular Disease Mortality, and All-Cause Mortality in a General Population of Middle-Aged Adults. 2019;8(16):e012865.

36. Appleby PN, Crowe FL, Bradbury KE, Travis RC, Key TJJTAjocn. Mortality in vegetarians and comparable nonvegetarians in the United Kingdom. 2016;103(1):218-30.

37. Orlich MJ, Singh PN, Sabate J, Jaceldo-Siegl K, Fan J, Knutsen S, et al. Vegetarian dietary patterns and mortality in Adventist Health Study 2. 2013;173(13):1230-8.

38. Renata Micha R, Wallace SK, Mozaffarian D. Red and processed meat consumption and risk of incident coronary heart disease, stroke, and diabetes mellitus. 2010.

39. Wang X, Lin X, Ouyang YY, Liu J, Zhao G, Pan A, et al. Red and processed meat consumption and mortality: dose-response meta-analysis of prospective cohort studies. 2016;19(5):893-905.

40. Bray GA, Lovejoy JC, Smith SR, DeLany JP, Lefevre M, Hwang D, et al. The influence of different fats and fatty acids on obesity, insulin resistance and inflammation. 2002;132(9):2488-91.

41. Van Dam RM, Willett WC, Rimm EB, Stampfer MJ, Hu FBJDc. Dietary fat and meat intake in relation to risk of type 2 diabetes in men. 2002;25(3):417-24.

42. Afshin A, Micha R, Khatibzadeh S, Mozaffarian DJTAjocn. Consumption of nuts and legumes and risk of incident ischemic heart disease, stroke, and diabetes: a systematic review and meta-analysis. 2014;100(1):278-88.

43. Ascherio A, Willett WC, Rimm EB, Giovannucci EL, Stampfer MJJC. Dietary iron intake and risk of coronary disease among men. 1994;89(3):969-74.

Table 1. Examples of Food Items Constituting the 18 Food Groups

\begin{tabular}{lllll}
\hline & $\begin{array}{l}\text { Plant Food } \\
\text { Groups }\end{array}$ & PDI & hPDI & uPDI \\
\hline $\begin{array}{l}\text { Healthy } \\
\text { Whole grains }\end{array}$ & $\begin{array}{l}\text { Cooked oatmeal, } \\
\text { dark bread, other } \\
\text { grains }\end{array}$ & Positive scores & Positive scores & Reverse scores \\
\hline
\end{tabular}




\begin{tabular}{|c|c|c|c|c|}
\hline & $\begin{array}{l}\text { Plant Food } \\
\text { Groups }\end{array}$ & PDI & hPDI & $\mathrm{uPDI}$ \\
\hline Fruits & $\begin{array}{l}\text { Watermelon, fresh } \\
\text { apples or pears, } \\
\text { oranges, } \\
\text { grapefruit, lemon, } \\
\text { fig, nectarine, } \\
\text { kiwi, persimmon, } \\
\text { tangerine, } \\
\text { peaches, } \\
\text { cantaloupe, } \\
\text { melon, } \\
\text { pomegranate, } \\
\text { date, } \\
\text { strawberries, } \\
\text { apricots or plums, } \\
\text { cherry, Raisins or } \\
\text { grapes, bananas, } \\
\text { pineapple }\end{array}$ & Positive scores & Positive scores & Reverse scores \\
\hline Vegetables & $\begin{array}{l}\text { Tomatoes, broccoli, } \\
\text { cabbage, } \\
\text { cauliflower, carrots, } \\
\text { mixed vegetables, } \\
\text { yellow or winter } \\
\text { squash, eggplant or } \\
\text { zucchini, spinach } \\
\text { cooked, spinach } \\
\text { raw, leaf lettuce, } \\
\text { celery, mushrooms, } \\
\text { beets, garlic, onion }\end{array}$ & Positive scores & Positive scores & Reverse scores \\
\hline Nuts & $\begin{array}{l}\text { Nuts, peanut } \\
\text { butter }\end{array}$ & Positive scores & Positive scores & Reverse scores \\
\hline Legumes & $\begin{array}{l}\text { String beans, } \\
\text { soybeans, beans } \\
\text { or lentils, peas or } \\
\text { beans }\end{array}$ & Positive scores & Positive scores & Reverse scores \\
\hline Vegetable oils & Olive, olive oil & Positive scores & Positive scores & Reverse scores \\
\hline $\begin{array}{l}\text { Tea and coffee } \\
\text { Less healthy }\end{array}$ & Tea, coffee & Positive scores & Positive scores & Reverse scores \\
\hline Fruit juices & $\begin{array}{l}\text { Apple juice, } \\
\text { orange juice, } \\
\text { grapefruit juice, } \\
\text { other fruit Juice }\end{array}$ & Positive scores & Reverse scores & Positive scores \\
\hline Refined grains & $\begin{array}{l}\text { Refined grains, } \\
\text { white bread, } \\
\text { biscuits, white } \\
\text { rice, crackers, } \\
\text { cake, macaroni, } \\
\text { vermicelli }\end{array}$ & Positive scores & Reverse scores & Positive scores \\
\hline
\end{tabular}




\begin{tabular}{|c|c|c|c|c|}
\hline & $\begin{array}{l}\text { Plant Food } \\
\text { Groups }\end{array}$ & PDI & hPDI & uPDI \\
\hline Potatoes & $\begin{array}{l}\text { French fries, } \\
\text { baked or mashed } \\
\text { potatoes, potato } \\
\text { or chips }\end{array}$ & Positive scores & Reverse scores & Positive scores \\
\hline $\begin{array}{l}\text { Sugar sweetened } \\
\text { beverages }\end{array}$ & Colas & Positive scores & Reverse scores & Positive scores \\
\hline Sweets and desserts & $\begin{array}{l}\text { Chocolates, candy } \\
\text { bars, candy without } \\
\text { chocolate, cookies } \\
\text { (home-baked and } \\
\text { ready-made), cake } \\
\text { (home-baked and } \\
\text { ready-made), jams } \\
\text { or jellies or } \\
\text { preserves or syrup } \\
\text { or honey } \\
\text { Animal Food } \\
\text { Groups }\end{array}$ & Positive scores & Reverse scores & Positive scores \\
\hline Animal fat & $\begin{array}{l}\text { Butter added to } \\
\text { food, butter or } \\
\text { lard used for } \\
\text { cooking }\end{array}$ & Reverse scores & Reverse scores & Reverse scores \\
\hline Dairy & $\begin{array}{l}\text { Skim low fat milk, } \\
\text { whole milk, cream, } \\
\text { sour cream, ice } \\
\text { cream, yogurt, dried } \\
\text { whey cream cheese, } \\
\text { other cheese }\end{array}$ & Reverse scores & Reverse scores & Reverse scores \\
\hline Egg & Eggs & Reverse scores & Reverse scores & Reverse scores \\
\hline Fish or seafood & $\begin{array}{l}\text { Canned tuna, } \\
\text { other fish }\end{array}$ & Reverse scores & Reverse scores & Reverse scores \\
\hline Meat & $\begin{array}{l}\text { Chicken with } \\
\text { skin, chicken } \\
\text { without skin, } \\
\text { processed meats, } \\
\text { liver, hamburger, } \\
\text { hot dog, beef or } \\
\text { lamb mixed dish, } \\
\text { kielbasa }\end{array}$ & Reverse scores & Reverse scores & Reverse scores \\
\hline Other & $\begin{array}{l}\text { Pizza, mayonnaise } \\
\text { or other creamy } \\
\text { salad dressing, } \\
\text { puff, salt }\end{array}$ & Reverse scores & Reverse scores & Reverse scores \\
\hline
\end{tabular}

$\mathrm{FFQ}=$ food frequency questionnaire; hPDI $=$ healthful plant-based diet index; PDI $=$ overall plant-based diet index; uPDI = unhealthful plant-based diet index 


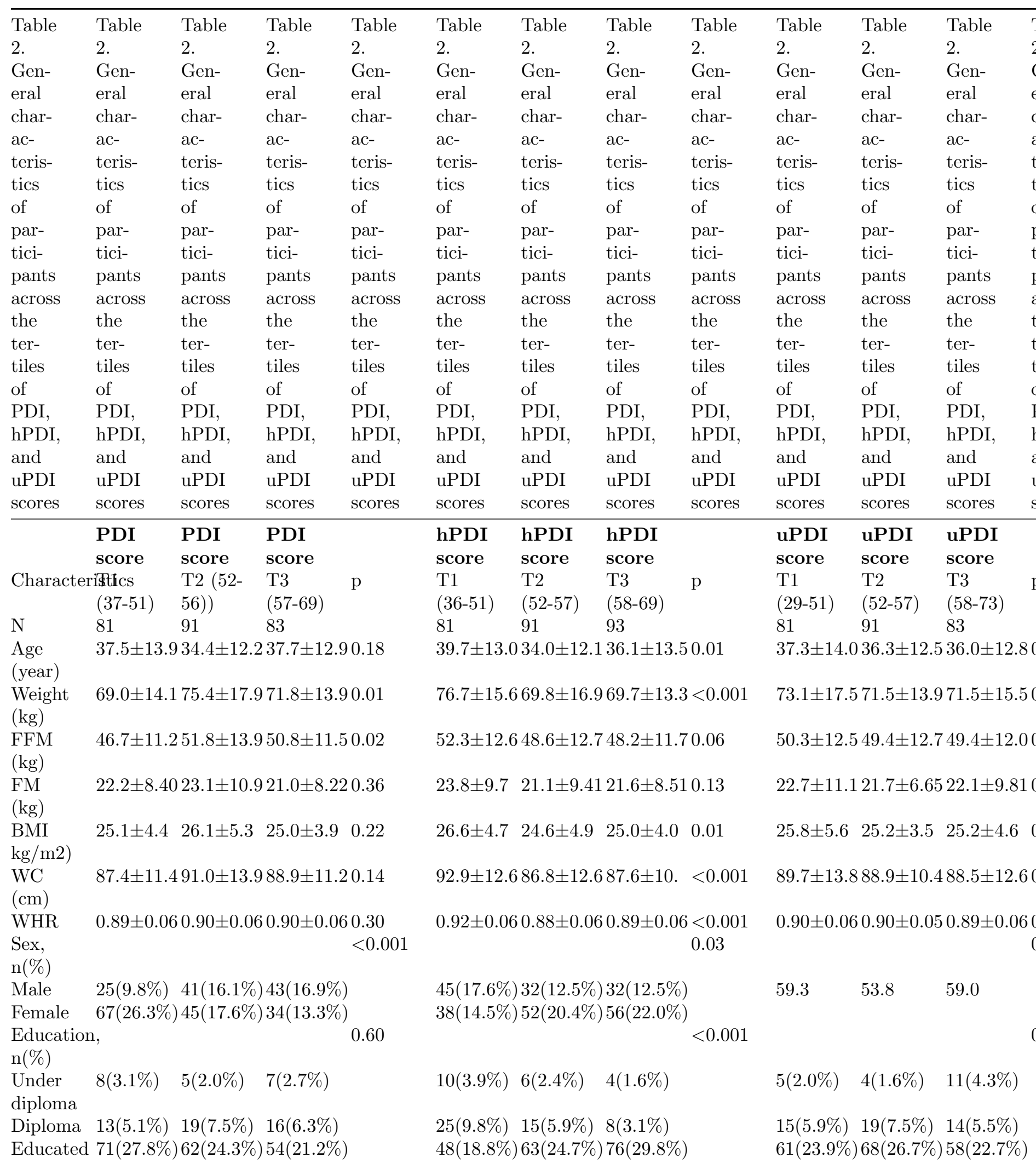




\begin{tabular}{|c|c|c|c|c|c|c|c|c|c|c|c|}
\hline Table & Table & Table & Table & Table & Table & Table & Table & Table & Table & Table & Table \\
\hline 2. & 2. & 2. & 2. & 2. & 2. & 2. & 2. & 2. & 2. & 2. & 2. \\
\hline $\begin{array}{l}\text { Gen- } \\
\text { eral } \\
\text { char- }\end{array}$ & $\begin{array}{l}\text { Gen- } \\
\text { eral } \\
\text { char- }\end{array}$ & $\begin{array}{l}\text { Gen- } \\
\text { eral } \\
\text { char- }\end{array}$ & $\begin{array}{l}\text { Gen- } \\
\text { eral } \\
\text { char- }\end{array}$ & $\begin{array}{l}\text { Gen- } \\
\text { eral } \\
\text { char- }\end{array}$ & $\begin{array}{l}\text { Gen- } \\
\text { eral } \\
\text { char- }\end{array}$ & $\begin{array}{l}\text { Gen- } \\
\text { eral } \\
\text { char- }\end{array}$ & $\begin{array}{l}\text { Gen- } \\
\text { eral } \\
\text { char- }\end{array}$ & $\begin{array}{l}\text { Gen- } \\
\text { eral } \\
\text { char- }\end{array}$ & $\begin{array}{l}\text { Gen- } \\
\text { eral } \\
\text { char- }\end{array}$ & $\begin{array}{l}\text { Gen- } \\
\text { eral } \\
\text { char- }\end{array}$ & $\begin{array}{l}\text { Gen- } \\
\text { eral } \\
\text { char- }\end{array}$ \\
\hline $\begin{array}{l}\text { ac- } \\
\text { teris- } \\
\text { tics }\end{array}$ & $\begin{array}{l}\text { ac- } \\
\text { teris- } \\
\text { tics }\end{array}$ & $\begin{array}{l}\text { ac- } \\
\text { teris- } \\
\text { tics }\end{array}$ & $\begin{array}{l}\text { ac- } \\
\text { teris- } \\
\text { tics }\end{array}$ & $\begin{array}{l}\text { ac- } \\
\text { teris- } \\
\text { tics }\end{array}$ & $\begin{array}{l}\text { ac- } \\
\text { teris- } \\
\text { tics }\end{array}$ & $\begin{array}{l}\text { ac- } \\
\text { teris- } \\
\text { tics }\end{array}$ & $\begin{array}{l}\text { ac- } \\
\text { teris- } \\
\text { tics }\end{array}$ & $\begin{array}{l}\text { ac- } \\
\text { teris- } \\
\text { tics }\end{array}$ & $\begin{array}{l}\text { ac- } \\
\text { teris- } \\
\text { tics }\end{array}$ & $\begin{array}{l}\text { ac- } \\
\text { teris- } \\
\text { tics }\end{array}$ & $\begin{array}{l}\text { ac- } \\
\text { teris- } \\
\text { tics }\end{array}$ \\
\hline of & of & of & of & of & of & of & of & of & of & of & of \\
\hline par- & par- & par- & par- & par- & par- & par- & par- & par- & par- & par- & par- \\
\hline $\begin{array}{l}\text { tici- } \\
\text { pants }\end{array}$ & $\begin{array}{l}\text { tici- } \\
\text { pants }\end{array}$ & $\begin{array}{l}\text { tici- } \\
\text { pants }\end{array}$ & $\begin{array}{l}\text { tici- } \\
\text { pants }\end{array}$ & $\begin{array}{l}\text { tici- } \\
\text { pants }\end{array}$ & $\begin{array}{l}\text { tici- } \\
\text { pants }\end{array}$ & $\begin{array}{l}\text { tici- } \\
\text { pants }\end{array}$ & $\begin{array}{l}\text { tici- } \\
\text { pants }\end{array}$ & $\begin{array}{l}\text { tici- } \\
\text { pants }\end{array}$ & $\begin{array}{l}\text { tici- } \\
\text { pants }\end{array}$ & $\begin{array}{l}\text { tici- } \\
\text { pants }\end{array}$ & $\begin{array}{l}\text { tici- } \\
\text { pants }\end{array}$ \\
\hline across & across & across & across & across & across & across & across & across & across & across & across \\
\hline the & the & the & the & the & the & the & the & the & the & the & the \\
\hline ter- & ter- & ter- & ter- & ter- & ter- & ter- & ter- & ter- & ter- & ter- & ter- \\
\hline $\begin{array}{l}\text { tiles } \\
\text { of }\end{array}$ & $\begin{array}{l}\text { tiles } \\
\text { of }\end{array}$ & $\begin{array}{l}\text { tiles } \\
\text { of }\end{array}$ & $\begin{array}{l}\text { tiles } \\
\text { of }\end{array}$ & $\begin{array}{l}\text { tiles } \\
\text { of }\end{array}$ & $\begin{array}{l}\text { tiles } \\
\text { of }\end{array}$ & $\begin{array}{l}\text { tiles } \\
\text { of }\end{array}$ & tiles & tiles & tiles & tiles & tiles \\
\hline PDI, & PDI, & PDI, & PDI. & PDI, & PDI. & PDI. & PDI, & PDI, & $\begin{array}{l}\text { OI } \\
\text { PDI. }\end{array}$ & $\begin{array}{l}\text { O1 } \\
\text { PDI, }\end{array}$ & $\begin{array}{l}\text { OI } \\
\text { PDI }\end{array}$ \\
\hline hPDI, & hPDI, & hPDI, & hPDI, & hPDI, & hPDI, & hPDI, & hPDI, & hPDI, & hPDI, & hPDI, & hPDI, \\
\hline & and & and & and & and & and & and & and & and & and & and & and \\
\hline uPDI & uPDI & $\mathrm{uPDI}$ & $\mathrm{uPDI}$ & $\mathrm{uPDI}$ & uPDI & uPDI & $\mathrm{uPDI}$ & uPDI & uPDI & uPDI & uPDI \\
\hline scores & scores & scores & scores & scores & scores & scores & scores & scores & scores & scores & scores \\
\hline $\begin{array}{l}\text { Smoking, } \\
\mathrm{n}(\%)\end{array}$ & & & & 0.86 & & & & 0.81 & & & \\
\hline $\begin{array}{l}\text { Not } \\
\text { smoking }\end{array}$ & $82(32.2 \%)$ & $76(29.8 \%)$ & $64(25.1 \%)$ & & $73(28.6 \%)$ & $70(27.5 \%)$ & $79(31.0 \%)$ & & $68(26.7 \%)$ & $79(31.0 \%)$ & $75(29.4 \%)$ \\
\hline $\begin{array}{l}\text { Quit } \\
\text { smoking }\end{array}$ & $9(3.6 \%)$ & $8(3.2 \%)$ & $11(4.2 \%)$ & & $9(3.6 \%)$ & $11(4.4 \%)$ & $8(3.2 \%)$ & & $12(4.8 \%)$ & $10(4.0 \%)$ & $6(2.4 \%)$ \\
\hline Moderate & $1(0.4 \%)$ & $2(0.8 \%)$ & $2(0.8 \%)$ & & $1(0.4 \%)$ & $3(1.2 \%)$ & $1(0.4 \%)$ & & $1(0.4 \%)$ & $2(0.8 \%)$ & $2(0.8 \%)$ \\
\hline $\begin{array}{l}\text { and } \\
\text { high } \\
\text { smoking }\end{array}$ & & & & & & & & & & & \\
\hline Activity & & & & 0.50 & & & & 0.50 & & & \\
\hline $\begin{array}{l}\text { level, } \\
\mathrm{n}(\%)\end{array}$ & & & & & & & & & & & \\
\hline Low & $32(12.5 \%)$ & $39(15.3 \%)$ & $28(11.0 \%)$ & & $32(12.5 \%)$ & $29(11.4 \%)$ & $28(14.9 \%)$ & & $25(9.8 \%)$ & $41(16.1 \%)$ & $33(12.9 \%)$ \\
\hline Moderate & $43(16.9 \%)$ & $31(12.2 \%)$ & $31(12.2 \%)$ & & $35(13.7 \%)$ & $40(15.7 \%)$ & $30(11.8 \%)$ & & $35(13.7 \%)$ & $34(13.3 \%)$ & $36(14.1 \%)$ \\
\hline High & $17(6.7 \%)$ & $16(6.3 \%)$ & $18(7.1 \%)$ & & $16(6.3 \%)$ & $15(5.9 \%)$ & $20(7.8 \%)$ & & $21(8.2 \%)$ & $16(6.3 \%)$ & $14(5.5 \%)$ \\
\hline $\begin{array}{l}\text { Diabetes, } \\
\mathrm{n}(\%)\end{array}$ & & & & 0.94 & & & & 0.43 & & & \\
\hline Yes & $3(1.2 \%)$ & $3(1.2 \%)$ & $2(0.8 \%)$ & & $3(1.2 \%)$ & $1(0.4 \%)$ & $4(1.6 \%)$ & & $4(1.6 \%)$ & $2(0.8 \%)$ & $2(0.8 \%)$ \\
\hline No & $89(34.9 \%)$ & $83(32.5 \%)$ & $75(29.4 \%)$ & & $80(31.4 \%)$ & $83(32.5 \%)$ & $84(32.9 \%)$ & & $77(30.2 \%)$ & $89(34.9 \%)$ & $81(31.8 \%)$ \\
\hline $\begin{array}{l}\text { CVD, } \\
\mathrm{n}(\%)\end{array}$ & & & & 0.56 & & & & 0.56 & & & \\
\hline Yes & $1(0.4 \%)$ & $3(1.2 \%)$ & $2(0.8 \%)$ & & $3(1.2 \%)$ & $2(0.8 \%)$ & $1(0.4 \%)$ & & $3(1.2 \%)$ & $2(0.8 \%)$ & $1(0.4 \%)$ \\
\hline No & $91(35.8 \%)$ & $83(32.7 \%)$ & $74(29.1 \%)$ & & $80(31.5 \%)$ & $81(31.9 \%)$ & $87(34.3 \%)$ & & $78(30.7 \%)$ & $89(35.0 \%)$ & $81(31.9 \%)$ \\
\hline \multicolumn{12}{|c|}{$\begin{array}{l}\text { Menopause, } \\
\mathrm{n} \\
(\%)\end{array}$} \\
\hline Yes & $13(9.0 \%)$ & $11(7.6 \%)$ & $10(6.9 \%)$ & & $11(7.6 \%)$ & $8(5.5 \%)$ & $15(10.3 \%)$ & & $13(9.0 \%)$ & $7(4.8 \%)$ & $14(9.7 \%)$ \\
\hline No & $53(36.6 \%)$ & $34(23.5 \%)$ & $24(16.6 \%)$ & & $27(18.6)$ & $44(30.3 \%)$ & $40(27.6 \%)$ & & $34(23.4 \%)$ & $42(29.0 \%)$ & $35(24.1 \%)$ \\
\hline
\end{tabular}




\begin{tabular}{|c|c|c|c|c|c|c|c|c|c|c|c|}
\hline Table & Table & Table & Table & Table & Table & Table & Table & Table & Table & Table & Table \\
\hline 2. & 2. & 2. & 2. & 2. & 2. & 2. & 2. & 2. & 2. & 2. & 2. \\
\hline $\begin{array}{l}\text { Gen- } \\
\text { eral } \\
\text { char- }\end{array}$ & $\begin{array}{l}\text { Gen- } \\
\text { eral } \\
\text { char- }\end{array}$ & $\begin{array}{l}\text { Gen- } \\
\text { eral } \\
\text { char- }\end{array}$ & $\begin{array}{l}\text { Gen- } \\
\text { eral } \\
\text { char- }\end{array}$ & $\begin{array}{l}\text { Gen- } \\
\text { eral } \\
\text { char- }\end{array}$ & $\begin{array}{l}\text { Gen- } \\
\text { eral } \\
\text { char- }\end{array}$ & $\begin{array}{l}\text { Gen- } \\
\text { eral } \\
\text { char- }\end{array}$ & $\begin{array}{l}\text { Gen- } \\
\text { eral } \\
\text { char- }\end{array}$ & $\begin{array}{l}\text { Gen- } \\
\text { eral } \\
\text { char- }\end{array}$ & $\begin{array}{l}\text { Gen- } \\
\text { eral } \\
\text { char- }\end{array}$ & $\begin{array}{l}\text { Gen- } \\
\text { eral } \\
\text { char- }\end{array}$ & $\begin{array}{l}\text { Gen- } \\
\text { eral } \\
\text { char- }\end{array}$ \\
\hline $\begin{array}{l}\text { ac- } \\
\text { teris- } \\
\text { tics }\end{array}$ & $\begin{array}{l}\text { ac- } \\
\text { teris- } \\
\text { tics }\end{array}$ & $\begin{array}{l}\text { ac- } \\
\text { teris- } \\
\text { tics }\end{array}$ & $\begin{array}{l}\text { ac- } \\
\text { teris- } \\
\text { tics }\end{array}$ & $\begin{array}{l}\text { ac- } \\
\text { teris- } \\
\text { tics }\end{array}$ & $\begin{array}{l}\text { ac- } \\
\text { teris- } \\
\text { tics }\end{array}$ & $\begin{array}{l}\text { ac- } \\
\text { teris- } \\
\text { tics }\end{array}$ & $\begin{array}{l}\text { ac- } \\
\text { teris- } \\
\text { tics }\end{array}$ & $\begin{array}{l}\text { ac- } \\
\text { teris- } \\
\text { tics }\end{array}$ & $\begin{array}{l}\text { ac- } \\
\text { teris- } \\
\text { tics }\end{array}$ & $\begin{array}{l}\text { ac- } \\
\text { teris- } \\
\text { tics }\end{array}$ & $\begin{array}{l}\text { ac- } \\
\text { teris- } \\
\text { tics }\end{array}$ \\
\hline of & of & of & of & of & of & of & of & of & of & of & of \\
\hline par- & par- & par- & par- & par- & par- & par- & par- & par- & par- & par- & par- \\
\hline $\begin{array}{l}\text { tici- } \\
\text { pants }\end{array}$ & $\begin{array}{l}\text { tici- } \\
\text { pants }\end{array}$ & $\begin{array}{l}\text { tici- } \\
\text { pants }\end{array}$ & $\begin{array}{l}\text { tici- } \\
\text { pants }\end{array}$ & $\begin{array}{l}\text { tici- } \\
\text { pants }\end{array}$ & $\begin{array}{l}\text { tici- } \\
\text { pants }\end{array}$ & $\begin{array}{l}\text { tici- } \\
\text { pants }\end{array}$ & $\begin{array}{l}\text { tici- } \\
\text { pants }\end{array}$ & $\begin{array}{l}\text { tici- } \\
\text { pants }\end{array}$ & $\begin{array}{l}\text { tici- } \\
\text { pants }\end{array}$ & $\begin{array}{l}\text { tici- } \\
\text { pants }\end{array}$ & $\begin{array}{l}\text { tici- } \\
\text { pants }\end{array}$ \\
\hline $\begin{array}{l}\text { across } \\
\text { the }\end{array}$ & $\begin{array}{l}\text { across } \\
\text { the }\end{array}$ & $\begin{array}{l}\text { across } \\
\text { the }\end{array}$ & $\begin{array}{l}\text { across } \\
\text { the }\end{array}$ & $\begin{array}{l}\text { across } \\
\text { the }\end{array}$ & $\begin{array}{l}\text { across } \\
\text { the }\end{array}$ & $\begin{array}{l}\text { across } \\
\text { the }\end{array}$ & $\begin{array}{l}\text { across } \\
\text { the }\end{array}$ & $\begin{array}{l}\text { across } \\
\text { the }\end{array}$ & $\begin{array}{l}\text { across } \\
\text { the }\end{array}$ & $\begin{array}{l}\text { across } \\
\text { the }\end{array}$ & $\begin{array}{l}\text { across } \\
\text { the }\end{array}$ \\
\hline ter- & ter- & ter- & ter- & ter- & ter- & ter- & ter- & ter- & ter- & ter- & ter- \\
\hline tiles & tiles & tiles & tiles & tiles & tiles & tiles & tiles & tiles & tiles & tiles & tiles \\
\hline of & of & of & of & of & of & of & of & of & of & of & of \\
\hline PDI, & PDI, & PDI, & PDI, & PDI, & PDI, & PDI, & PDI, & PDI, & PDI, & PDI, & PDI, \\
\hline hPDI, & hPDI, & hPDI, & hPDI, & hPDI, & hPDI, & hPDI, & hPDI, & hPDI, & hPDI, & hPDI, & hPDI, \\
\hline and & and & and & and & and & and & and & and & and & and & and & and \\
\hline uPDI & uPDI & uPDI & uPDI & uPDI & uPDI & uPDI & uPDI & uPDI & uPDI & uPDI & uPDI \\
\hline scores & scores & scores & scores & scores & scores & scores & scores & scores & scores & scores & scores \\
\hline $\mathrm{P}$ & $\mathrm{P}$ & $\mathrm{P}$ & $\mathrm{P}$ & $\mathrm{P}$ & $\mathrm{P}$ & $\mathrm{P}$ & $\mathrm{P}$ & $\mathrm{P}$ & $\mathrm{P}$ & $\mathrm{P}$ & $\mathrm{P}$ \\
\hline value & value & value & value & value & value & value & value & value & value & value & value \\
\hline less & less & less & less & less & less & less & less & less & less & less & less \\
\hline than & than & than & than & than & than & than & than & than & than & than & than \\
\hline 0.05 & 0.05 & 0.05 & 0.05 & 0.05 & 0.05 & 0.05 & 0.05 & 0.05 & 0.05 & 0.05 & 0.05 \\
\hline was & was & was & was & was & was & was & was & was & was & was & was \\
\hline con- & con- & con- & con- & con- & con- & con- & con- & con- & con- & con- & con- \\
\hline sid- & sid- & sid- & sid- & sid- & sid- & sid- & sid- & sid- & sid- & sid- & sid- \\
\hline ered & ered & ered & ered & ered & ered & ered & ered & ered & ered & ered & ered \\
\hline sig- & sig- & sig- & sig- & sig- & sig- & sig- & sig- & sig- & sig- & sig- & sig- \\
\hline nifi- & nifi- & nifi- & nifi- & nifi- & nifi- & nifi- & nifi- & nifi- & nifi- & nifi- & nifi- \\
\hline cant. & cant. & cant. & cant. & cant. & cant. & cant. & cant. & cant. & cant. & cant. & cant. \\
\hline Val- & Val- & Val- & Val- & Val- & Val- & Val- & Val- & Val- & Val- & Val- & Val- \\
\hline ues & ues & ues & ues & ues & ues & ues & ues & ues & ues & ues & ues \\
\hline are & are & are & are & are & are & are & are & are & are & are & are \\
\hline based & based & based & based & based & based & based & based & based & based & based & based \\
\hline on & on & on & on & on & on & on & on & on & on & on & on \\
\hline aver- & aver- & aver- & aver- & aver- & aver- & aver- & aver- & aver- & aver- & aver- & aver- \\
\hline age & age & age & age & age & age & age & age & age & age & age & age \\
\hline \pm & \pm & \pm & \pm & \pm & \pm & \pm & \pm & \pm & \pm & \pm & \pm \\
\hline stan- & stan- & stan- & stan- & stan- & stan- & stan- & stan- & stan- & stan- & stan- & stan- \\
\hline dard & dard & dard & dard & dard & dard & dard & dard & dard & dard & dard & dard \\
\hline de- & de- & de- & de- & de- & de- & de- & de- & de- & de- & de- & de- \\
\hline viati- & viati- & viati- & viati- & viati- & viati- & viati- & viati- & viati- & viati- & viati- & viati- \\
\hline on or & on or & on or & on or & on or & on or & on or & on or & on or & on or & on or & on or \\
\hline re- & re- & re- & re- & re- & re- & re- & re- & re- & re- & re- & re- \\
\hline por- & por- & por- & por- & por- & por- & por- & por- & por- & por- & por- & por- \\
\hline ted & ted & ted & ted & ted & ted & ted & ted & ted & ted & ted & ted \\
\hline per- & per- & per- & per- & per- & per- & per- & per- & per- & per- & per- & per- \\
\hline cen- & cen- & cen- & cen- & cen- & cen- & cen- & cen- & cen- & cen- & cen- & cen- \\
\hline tage. & tage. & tage. & tage. & tage. & tage. & tage. & tage. & tage. & tage. & tage. & tage. \\
\hline One- & One- & One- & One- & One- & Onze- & One- & One- & One- & One- & One- & One- \\
\hline way & way & way & way & way & way & way & way & way & way & way & way \\
\hline ANO- & ANO- & ANO- & ANO- & ANO- & ANO- & ANO- & ANO- & ANO- & ANO- & ANO- & ANO- \\
\hline VA & VA & VA & VA & VA & VA & VA & VA & VA & VA & VA & VA \\
\hline for & for & for & for & for & for & for & for & for & for & for & for \\
\hline quan- & quan- & quan- & quan- & quan- & quan- & quan- & quan- & quan- & quan- & quan- & quan- \\
\hline
\end{tabular}




\begin{tabular}{|c|c|c|c|c|c|c|c|c|c|c|c|}
\hline Table & Table & Table & Table & Table & Table & Table & Table & Table & Table & Table & Table \\
\hline 2. & 2. & 2. & 2. & 2. & 2. & 2. & 2. & 2. & 2. & 2. & 2. \\
\hline $\begin{array}{l}\text { Gen- } \\
\text { eral } \\
\text { char- }\end{array}$ & $\begin{array}{l}\text { Gen- } \\
\text { eral } \\
\text { char- }\end{array}$ & $\begin{array}{l}\text { Gen- } \\
\text { eral } \\
\text { char- }\end{array}$ & $\begin{array}{l}\text { Gen- } \\
\text { eral } \\
\text { char- }\end{array}$ & $\begin{array}{l}\text { Gen- } \\
\text { eral } \\
\text { char- }\end{array}$ & $\begin{array}{l}\text { Gen- } \\
\text { eral } \\
\text { char- }\end{array}$ & $\begin{array}{l}\text { Gen- } \\
\text { eral } \\
\text { char- }\end{array}$ & $\begin{array}{l}\text { Gen- } \\
\text { eral } \\
\text { char- }\end{array}$ & $\begin{array}{l}\text { Gen- } \\
\text { eral } \\
\text { char- }\end{array}$ & $\begin{array}{l}\text { Gen- } \\
\text { eral } \\
\text { char- }\end{array}$ & $\begin{array}{l}\text { Gen- } \\
\text { eral } \\
\text { char- }\end{array}$ & $\begin{array}{l}\text { Gen- } \\
\text { eral } \\
\text { char- }\end{array}$ \\
\hline $\begin{array}{l}\text { ac- } \\
\text { teris- } \\
\text { tics }\end{array}$ & $\begin{array}{l}\text { ac- } \\
\text { teris- } \\
\text { tics }\end{array}$ & $\begin{array}{l}\text { ac- } \\
\text { teris- } \\
\text { tics }\end{array}$ & $\begin{array}{l}\text { ac- } \\
\text { teris- } \\
\text { tics }\end{array}$ & $\begin{array}{l}\text { ac- } \\
\text { teris- } \\
\text { tics }\end{array}$ & $\begin{array}{l}\text { ac- } \\
\text { teris- } \\
\text { tics }\end{array}$ & $\begin{array}{l}\text { ac- } \\
\text { teris- } \\
\text { tics }\end{array}$ & $\begin{array}{l}\text { ac- } \\
\text { teris- } \\
\text { tics }\end{array}$ & $\begin{array}{l}\text { ac- } \\
\text { teris- } \\
\text { tics }\end{array}$ & $\begin{array}{l}\text { ac- } \\
\text { teris- } \\
\text { tics }\end{array}$ & $\begin{array}{l}\text { ac- } \\
\text { teris- } \\
\text { tics }\end{array}$ & $\begin{array}{l}\text { ac- } \\
\text { teris- } \\
\text { tics }\end{array}$ \\
\hline of & of & of & of & of & of & of & of & of & of & of & of \\
\hline par- & par- & par- & par- & par- & par- & par- & par- & par- & par- & par- & par- \\
\hline $\begin{array}{l}\text { tici- } \\
\text { pants }\end{array}$ & $\begin{array}{l}\text { tici- } \\
\text { pants }\end{array}$ & $\begin{array}{l}\text { tici- } \\
\text { pants }\end{array}$ & $\begin{array}{l}\text { tici- } \\
\text { pants }\end{array}$ & $\begin{array}{l}\text { tici- } \\
\text { pants }\end{array}$ & $\begin{array}{l}\text { tici- } \\
\text { pants }\end{array}$ & $\begin{array}{l}\text { tici- } \\
\text { pants }\end{array}$ & $\begin{array}{l}\text { tici- } \\
\text { pants }\end{array}$ & $\begin{array}{l}\text { tici- } \\
\text { pants }\end{array}$ & $\begin{array}{l}\text { tici- } \\
\text { pants }\end{array}$ & $\begin{array}{l}\text { tici- } \\
\text { pants }\end{array}$ & $\begin{array}{l}\text { tici- } \\
\text { pants }\end{array}$ \\
\hline $\begin{array}{l}\text { across } \\
\text { the }\end{array}$ & $\begin{array}{l}\text { across } \\
\text { the }\end{array}$ & $\begin{array}{l}\text { across } \\
\text { the }\end{array}$ & $\begin{array}{l}\text { across } \\
\text { the }\end{array}$ & $\begin{array}{l}\text { across } \\
\text { the }\end{array}$ & $\begin{array}{l}\text { across } \\
\text { the }\end{array}$ & $\begin{array}{l}\text { across } \\
\text { the }\end{array}$ & $\begin{array}{l}\text { across } \\
\text { the }\end{array}$ & $\begin{array}{l}\text { across } \\
\text { the }\end{array}$ & $\begin{array}{l}\text { across } \\
\text { the }\end{array}$ & $\begin{array}{l}\text { across } \\
\text { the }\end{array}$ & $\begin{array}{l}\text { across } \\
\text { the }\end{array}$ \\
\hline $\begin{array}{l}\text { ter- } \\
\text { tiles }\end{array}$ & $\begin{array}{l}\text { ter- } \\
\text { tiles }\end{array}$ & $\begin{array}{l}\text { ter- } \\
\text { tiles }\end{array}$ & $\begin{array}{l}\text { ter- } \\
\text { tiles }\end{array}$ & $\begin{array}{l}\text { ter- } \\
\text { tiles }\end{array}$ & $\begin{array}{l}\text { ter- } \\
\text { tiles }\end{array}$ & $\begin{array}{l}\text { ter- } \\
\text { tiles }\end{array}$ & $\begin{array}{l}\text { ter- } \\
\text { tiles }\end{array}$ & $\begin{array}{l}\text { ter- } \\
\text { tiles }\end{array}$ & $\begin{array}{l}\text { ter- } \\
\text { tiles }\end{array}$ & $\begin{array}{l}\text { ter- } \\
\text { tiles }\end{array}$ & $\begin{array}{l}\text { ter- } \\
\text { tiles }\end{array}$ \\
\hline of & of & of & of & of & of & of & of & of & of & of & of \\
\hline PDI, & PDI, & PDI, & PDI, & PDI, & PDI, & PDI, & PDI, & PDI, & PDI, & PDI, & PDI, \\
\hline $\begin{array}{l}\text { hPDI, } \\
\text { and }\end{array}$ & $\begin{array}{l}\text { hPDI, } \\
\text { and }\end{array}$ & $\begin{array}{l}\text { hPDI, } \\
\text { and }\end{array}$ & $\begin{array}{l}\text { hPDI, } \\
\text { and }\end{array}$ & $\begin{array}{l}\text { hPDI, } \\
\text { and }\end{array}$ & $\begin{array}{l}\text { hPDI, } \\
\text { and }\end{array}$ & $\begin{array}{l}\text { hPDI, } \\
\text { and }\end{array}$ & $\begin{array}{l}\text { hPDI, } \\
\text { and }\end{array}$ & $\begin{array}{l}\text { hPDI, } \\
\text { and }\end{array}$ & $\begin{array}{l}\text { hPDI, } \\
\text { and }\end{array}$ & $\begin{array}{l}\text { hPDI, } \\
\text { and }\end{array}$ & $\begin{array}{l}\text { hPDI, } \\
\text { and }\end{array}$ \\
\hline uPDI & uPDI & uPDI & uPDI & uPDI & uPDI & uPDI & uPDI & uPDI & uPDI & uPDI & uPDI \\
\hline scores & scores & scores & scores & scores & scores & scores & scores & scores & scores & scores & scores \\
\hline
\end{tabular}

Table 3. Mean and standard deviation of food groups across tertiles of PDI, hPDI, and uPDI scores

Food groups

n

Whole grains (g/day)

Fruits (g/day)

Vegetables (g/day)

Nuts (g/day)

Legumes(g/day)

Vegetables Oils (g/day)

Tea and Coffee (g/day)

Fruit juices (g/day)

Refined grains (g/day)

Potatoes (g/day)

Sugar sweetened beverages(g/day)

Sweets and dessert (g/day)

Animal fat(g/day)

Dairy (g/day)

$\operatorname{Egg}(\mathrm{g} /$ day)

Fish or seafood (g/day)

Meat (g/day)

Other (g/day)

ANOVA was used for statistical comparisons between quantitative variables, and chi-square test was used for statistical con 
Table 4. Dietary intakes across tertiles of PDI, hPDI, and uPDI scores

\section{Biomarkers}

Thiamin, $\mathrm{mg} / \mathrm{d}$

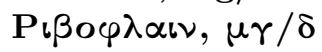

Niacin, mg/d

Pyridoxine, mg/d

Folate, mg/d

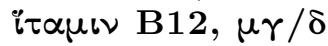

Vitamin E, mg/d

Vitamin D, IU/d

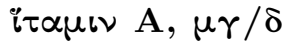

Vitamin C, mg/d

i $\alpha \mu \iota \mathrm{K}, \mu \gamma / \delta$

$\mathrm{K}, \mathbf{m g} / \mathbf{d}$

$\mathrm{Na}, \mathrm{mg} / \mathrm{d}$

$\mathrm{Ca}, \mathrm{mg} / \mathrm{d}$

$\mathrm{Mg}, \mathrm{mg} / \mathrm{d}$

Fe, $\mathrm{mg} / \mathrm{d}$

Se, $\mathrm{mg} / \mathrm{d}$

Zn, mg/d

$\mathrm{P}$ value less than 0.05 was considered significant. Values are based on mean \pm standard deviation PDI: plant based diet ind

Table5.mean and standard deviation of body composition and traditic

Table 6. Multivariate adjusted odds ratios and 95\% confidence intervals for CVD risk factors across tertiles of PDI, hPDI a

General Obesity

Central obesity 
Table 6. Multivariate adjusted odds ratios and 95\% confidence intervals for CVD risk factors across tertiles of PDI, hPDI a

Hypertension

Visceral adiposity

Hypertriglyceridemia

Hyperglycemia

LAP

TyG

General Obesity

Central obesity

Hypertension

Visceral adiposity

Hypertriglyceridemia

Hyperglycemia

LAP

TyG

General Obesity $(\mathrm{cm})$

Central obesity $(\mathrm{cm})$

Hypertension( $\mathrm{mmHg}$ )

Visceral adiposity

Hypertriglyceridemia (mg/dL)

Hyperglycemia(mg/dL)

LAP

TyG

$\mathrm{P}$ value Adjusted for age, sex, education, physical activity, smoking, , CVD, diabetes, menopause status and energy intake.

\section{Hosted file}

Table 1.docx available at https://authorea.com/users/335562/articles/461436-the-associationof-plant-based-dietary-patterns-with-visceral-adiposity-lipid-accumulation-product-andtriglyceride-glucose-index-in-iranian-adults

\section{Hosted file}

Table 2.docx available at https://authorea.com/users/335562/articles/461436-the-associationof-plant-based-dietary-patterns-with-visceral-adiposity-lipid-accumulation-product-andtriglyceride-glucose-index-in-iranian-adults

\section{Hosted file}

Table 3.docx available at https://authorea.com/users/335562/articles/461436-the-associationof-plant-based-dietary-patterns-with-visceral-adiposity-lipid-accumulation-product-andtriglyceride-glucose-index-in-iranian-adults

\section{Hosted file}

Table 4.docx available at https://authorea.com/users/335562/articles/461436-the-associationof-plant-based-dietary-patterns-with-visceral-adiposity-lipid-accumulation-product-andtriglyceride-glucose-index-in-iranian-adults

\section{Hosted file}

Table 5.docx available at https://authorea.com/users/335562/articles/461436-the-association- 
of-plant-based-dietary-patterns-with-visceral-adiposity-lipid-accumulation-product-andtriglyceride-glucose-index-in-iranian-adults

\section{Hosted file}

Table 6.docx available at https://authorea.com/users/335562/articles/461436-the-associationof-plant-based-dietary-patterns-with-visceral-adiposity-lipid-accumulation-product-andtriglyceride-glucose-index-in-iranian-adults 